\title{
Measuring the Relationship between Crude Oil Price, Stock Market and Gold Price with Reference India
}

\author{
Sivasubramanian K, Jaheer Mukthar K. P., \& Raju. V \\ Department of Economics, Kristu Jayanti College, Bengaluru, India \\ jaheermukhtar@gmail.com
}

\begin{abstract}
India is one among the highly potential market for the oil consumption. When we are considering the industrial line, natural gas and oil industry, it portraits a great significant influence on the economic growth and development through the GDP and per capita flow of income. The year-wise statistics was collected for two decades from 2000 to 2019 and the everyday prices such as gold price, Nifty opinions and Crude oil prices are intended and taken the annual averages of it. The aim for selecting the data from the year 2000 to 2019 is very vital. It was selected to find out the influence of new financial policy 1991 after 10 years of its application. Moreover, the main implication of this work is to find the causal association among these financial variables. The price of gold is considered as 24 carat, the average price was taken for analysis. The ANOVA model has been applied to predict the relationship between the variables in order to find out the cause and effect. It reveals the positive correlation between the variables. It is also revealed from the study that the price of gold had an exponential increase over a period of two decades and alongside the Nifty points also increased in the same period of time. On the whole, it is found from the data that the gold price is having the positive relation with Nifty points of the stock market and the crude oil price did not have any influence on the determination of gold price.
\end{abstract}

Keyword: Crude Oil Price, Stock Market, Gold Price, MANOVA, India

\section{How to Cite}

Sivasubramanian, K., Jaheer Mukthar. K. P., \& Raju, V. (2021). Measuring the relationship between crude oil price, stock market and gold price with reference India. International Journal of Finance Resarch, 2(1). 37-45. DOI : https://doi.org/10.47747/ijfr.v2i1.245

\section{Introduction}

Gold is labelled as valuable metal and the gold is called as eminence of identity of people in India. It is taking a very important worth in two methods namely traditional importance and investment value. The traditional value ascends as the gilded is careful as a promising product. The speculation value ascends due to its inflationary nature. There are many details for the Indian persons to purchase gold such as slushy value, extended term investment, asset formation, expressive values, and inflation for corporate gifting and rewards. It is quite significant to study the nature and determination of the oil prices in India. India is one among the highly potential market for the oil consumption. When we are considering the industrial line, natural gas and oil industry, it portraits a great significant influence on the economic growth and development 
through the GDP and per capita flow of income. It has been recoded as fifteen percent of India's gross domestic product. The monthly oil prices trend have been given for December 2020 as follows, the petrol and diesel have opened the first day of December starting at 82.34 rupees and 72.42 rupees per litre in India. While compare to the closing price of the last month prior to December 2020, both the petrol and the diesel price have fluctuated greatly in India. It has been registered as 82.34 rupees per litre and the diesel reached at 72.42 per litre. The chief idea behindhand the gold and oil relative is the one which proposes that prices of crude oil partially account for inflation. Increases in the price of oil result in increased prices of gasoline which is derived from oil. If gasoline is more expensive, than it's more costly to transport goods and their prices go up. There are factors which influences the fuel prices such as cost of raw petroleum (crude oil),

\section{Literature Review}

Sjaastad (2008) inspects the experiential and hypothetical connotation between main stock conversation charges and gold rate by smearing prediction error of data. It exposed the vacillations in the worth of gold caused from detached exchange proportions of numerous currencies. He too established that the association among the two variables are straight and it was mostly influenced on the basis of dollar price. Harry et al (2009) strained to prove the association amongst unpolished oil, discussion rate and creation marketplace price of agrarian goods. They have made arithmetical test such as ADF test and Johensen test over an epoch of time and it established that there was no long term. Patel (2013) endeavored to found the unpremeditated connotation between Indian stock market and value of the gold in India. His work is tested that all connected variables are in motionless in Augmented Dickey-Fuller numerical test, the co-integration test demonstrates that there is a stock overtone amid gold prices and all stock directories and the Grager Causality arithmetical test established that causality inaugurates from gold price to stock exchange values.

Subashini \& Poornima (2014) have made an efforts to check the association among gold, crude oil price and dollar exchange rate in India by applying daily figures for the time period from first January 2009 to till $31^{\text {st }}$ December 2013 . They originated from the study that all three variables are directly correlated.

Girish et al (2015) exhibits the relationship between exchange rates of American currency against Indian rupee and gold price in India. The study stresses the changes in gold price due to fluctuations in exchange rates before and after recessional periods. The data was tested with granger causality and found that relationship is direct between the two variables.

Tripathy (2016) meant to discover the short and long run connotation amid the price of gold and the stock market in India. The results of his study reveals that the stock market and the price of gold are at stationary at its level. The consequences have found that there is no causal association between the variables. But in additional arithmetical test, the study found a long run association between the gold price and stock market.

Ranjusha et al (2017) examined to establish the connection between the value of gold and exchange rate market. The examination exposed that the there was a integration among the two variables by smearing arithmetical tools and verified by the hypothesis. 
Sankararaman et al (2018) observed that the long term connotation between the American dollar exchange values and the 5 selected product prices. Among the 5 goods two are gold and crude oil, which is consuming the unintended association with conversation rate of dollar.

Muhammad, Ashiq AM \& Shanmugasundaram, G (2020) in their paper evaluated the impact of oil prices and exchange price on a sectoral level for Indian stock market and reported the exchange rate is having great influence on stock indices as compare with oil process.

\section{Research Methodology}

This contemporary study was conceded out with the provision of ancillary data composed from numerous sources such as gold council of India, National Stock Exchange and Security Exchange Board of India (SEBI). The year-wise statistics was collected for two decades from 2000 to 2019 and the everyday prices such as gold price, Nifty opinions and Crude oil prices are intended and taken the annual averages of it. The aim for selecting the data from the year 2000 to 2019 is very vital. It was selected to find out the influence of new financial policy 1991 after 10 years of its application. Moreover, the main implication of this work is to find the causal association among these financial variables. The price of gold is considered as 24 carat, the average price was taken for analysis. The value of Crude oil and Nifty points were also yearly means are taken. The present investigation applied numerous econometric implements such as Johensen cointegration, Granger causality to observe long period suggestion between the economic variables. This study also analyzed the association between the variables.

\section{Analysis and Interpretation of Results}

The mean price of the gold from 2000 to 2019 have been collected for the study purpose.

Table.1 Average Price of Gold, Nifty Points from Year 2000 to 2019

\begin{tabular}{|c|c|l|c|}
\hline Year & $\begin{array}{c}\text { Gold Price } \\
\text { 24ct (p/g) }\end{array}$ & Nifty Points & $\begin{array}{c}\text { Crude } \\
\text { Oil } \\
\text { Price } \mathbf{( \$ )}\end{array}$ \\
\hline 2000 & 440 & 1417.6174 & 30.38 \\
\hline 2001 & 430 & 1121.012551 & 25.98 \\
\hline 2002 & 499 & 1056.0244 & 26.19 \\
\hline 2003 & 560 & 1234.233004 & 31.08 \\
\hline 2004 & 585 & 1755.250791 & 41.51 \\
\hline 2005 & 700 & 2268.910558 & 56.64 \\
\hline 2006 & 840 & 3357.0938 & 66.05 \\
\hline 2007 & 1080 & 4571.292369 & 72.34 \\
\hline 2008 & 1250 & 4331.744898 & 99.67 \\
\hline 2009 & 1450 & 4118.425 & 61.95 \\
\hline 2010 & 1850 & 5461.124603 & 79.48 \\
\hline 2011 & 2640 & 5335.912551 & 94.88 \\
\hline 2012 & 3105 & 5325.298008 & 94.05 \\
\hline 2013 & 2960 & 5915.764859 & 97.98 \\
\hline
\end{tabular}


Vol. 2, No. 1, March 2021

\begin{tabular}{|c|c|c|c|}
\hline 2014 & 2800 & 7364.659671 & 93.17 \\
\hline 2015 & 2634 & 8285.924696 & 48.72 \\
\hline 2016 & 2862 & 8092.718293 & 43.58 \\
\hline 2017 & 2966 & 9590.717944 & 50.84 \\
\hline 2018 & 3143 & 10750.67327 & 64.9 \\
\hline 2019 & 3522 & 11434.77377 & 57.05 \\
\hline
\end{tabular}

Source: SEBI \& NIFTY, Various Years

The price of the gold has increased exponentially over a period of time from the year 2000 to 2019. It was increased from Rs.440 per gram for 24 carat gold to 3522 in the year 2019.

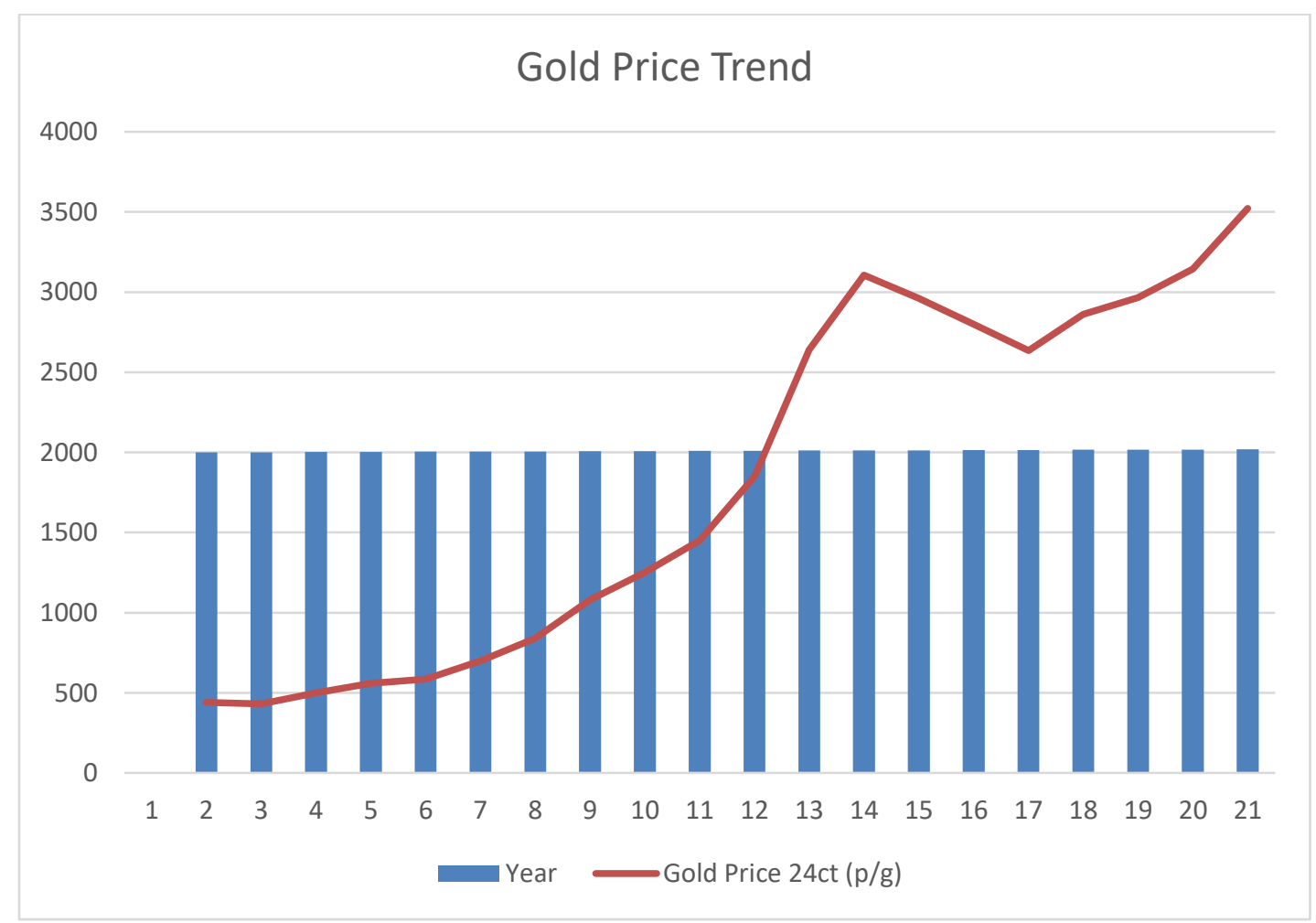

\section{Figure 1. Gold Price Trend}

The price trend of NIFTY also registered a grated increase over a period of two decades from 1417 to 11434 points. 




Figure 2. Trend of Nifty Points

The crude oil price have not shown a greater changes as gold and the NIFTY point changes. It is evident from the collected data, the crude oil price have grate fluctuations of up and down.



Figure 3. Trend Crude oil Price

Following table 2 brings the descriptive statistics of the collected data such as minimum, maximum and mean value of gold price, Nifty points and crude oil.

Table. 2 Descriptive Statistics

\begin{tabular}{|l|r|r|r|r|r|}
\hline & N & \multicolumn{1}{|c|}{$\begin{array}{c}\text { Minimu } \\
\mathrm{m}\end{array}$} & \multicolumn{1}{c|}{$\begin{array}{c}\text { Maximu } \\
\mathrm{m}\end{array}$} & Mean & \multicolumn{1}{c|}{$\begin{array}{c}\text { Std. } \\
\text { Deviation }\end{array}$} \\
\hline Gold Price & 20 & 430.00 & 3522.00 & 1815.8000 & 1128.84541 \\
Nifty Points & 20 & 1056.02 & 11434.77 & 5139.4586 & 3261.38398 \\
Crude Oil & 20 & 25.98 & 99.67 & 61.8220 & 25.00425 \\
Valid N (listwise) & 20 & & & & \\
\hline
\end{tabular}


Vol. 2, No. 1, March 2021

The minimum price was Rs.430 for gold and the maximum is recorded as 3522 with the average of 1815.80 rupees. The Nifty point's minimum was 1056.02 and the maximum of 11434.77 with the mean value of 5139.45686. Likewise, the crude oil price was recoded with the minimum value of 25.98 and maximum was 99.67 with the mean value of 61.8220 .

\subsection{Correlation Between The Variables}

The correlation between gold price and Nifty were calculated. The correlation is significant at 0.000 level. It is found from the analysis that the gold price and the Nifty points are having the positive correlation between these variables.

Table. 3 Correlations

\begin{tabular}{|rl|r|r|}
\hline & & Gold Price & Nifty Points \\
\hline \multirow{5}{*}{ Gold_Price } & Pearson & 1 & $.912^{* *}$ \\
& Correlation & & \\
& Sig. (2-tailed) & & .000 \\
& N & 20 & 20 \\
& Pearson & $.912^{* *}$ & 1 \\
Nifty_Points & Correlation & & \\
& Sig. (2-tailed) & .000 & 20 \\
& N & 20 & \\
\hline
\end{tabular}

**. Correlation is significant at the 0.01 level (2-tailed).

It is also found from the study that there was a positive correlation between gold price and the crude oil price in India.

Table. 4 Correlation

\begin{tabular}{|ll|r|r|}
\hline & & Gold Price & Crude Oil \\
\hline \multirow{4}{*}{ Gold Price } & Pearson & 1 & $.505^{*}$ \\
& Correlation & & \\
& Sig. (2-tailed) & & .023 \\
& $\mathrm{~N}$ & 20 & 20 \\
& Pearson & $.505^{*}$ & 1 \\
Crude Oil & Correlation & & \\
& Sig. (2-tailed) & .023 & \\
& $\mathrm{~N}$ & 20 & 20 \\
\hline
\end{tabular}

Table. 5 Correlation

\begin{tabular}{|ll|r|r|}
\hline & \multicolumn{1}{|c|}{$\begin{array}{c}\text { Nifty } \\
\text { Points }\end{array}$} & Crude Oil \\
\hline \multirow{4}{*}{ Nifty Points } & Pearson & 1 & .339 \\
& Correlation & & \\
& Sig. (2-tailed) & & .144 \\
& $\mathrm{~N}$ & 20 & 20
\end{tabular}


Vol. 2, No. 1, March 2021

\begin{tabular}{|ll|r|r|} 
& Pearson & .339 & 1 \\
Crude Oil & Correlation & & \\
& Sig. (2-tailed) & .144 & \\
& $\mathrm{~N}$ & 20 & 20 \\
\hline
\end{tabular}

\subsection{Regression Analysis}

Table 6. Model Fitting Information

\begin{tabular}{|c|c|c|c|c|}
\hline Model & $\begin{array}{c}-2 \text { Log } \\
\text { Likelihood }\end{array}$ & Chi-Square & df & Sig. \\
\hline $\begin{array}{c}\text { Intercept Only } \\
\text { Final }\end{array}$ & $\begin{array}{c}119.829 \\
.000\end{array}$ & 119.829 & 19 & .000 \\
\hline
\end{tabular}

Link function: Logit.

Table 7. Goodness-of-Fit

\begin{tabular}{|c|c|c|c|}
\hline & $\begin{array}{c}\text { Chi- } \\
\text { Square }\end{array}$ & df & Sig. \\
\hline Pearson & 12.778 & 342 & 1.000 \\
Deviance & 18.861 & 342 & 1.000 \\
\hline
\end{tabular}

Link function: Logit.

The regression model is very much fit for the present data set and executed for the further analysis to figure out the

Table 8. Model Summary

\begin{tabular}{|c|c|c|c|c|}
\hline $\begin{array}{c}\text { Mode } \\
1\end{array}$ & $\mathrm{R}$ & $\mathrm{R}$ Square & $\begin{array}{c}\text { Adjusted R } \\
\text { Square }\end{array}$ & $\begin{array}{c}\text { Std. Error of } \\
\text { the Estimate }\end{array}$ \\
\hline 1 & $.935^{\mathrm{a}}$ & .875 & .860 & 421.71597 \\
\hline
\end{tabular}

a. Predictors: (Constant), Crude_Oil, Nifty_Points

Table 9. ANOVA ${ }^{\mathrm{a}}$

\begin{tabular}{|cc|c|c|c|c|c|}
\hline \multicolumn{1}{|c|}{ Model } & Sum of Squares & df & Mean Square & F & Sig. \\
\hline \multirow{4}{*}{1} & Regression & 21188193.121 & 2 & 10594096.560 & 59.569 & $.000^{\mathrm{b}}$ \\
& Residual & 3023354.079 & 17 & 177844.358 & & \\
\hline & Total & 24211547.200 & 19 & & & \\
\hline
\end{tabular}

a. Dependent Variable: Gold_Price

b. Predictors: (Constant), Crude_Oil, Nifty_Points

The ANOVA model has been applied to predict the relationship between the variables in order to find out the cause and effect. The calculated $\mathrm{F}$ value of 59.569 with the significance at 0.000 level. It reveals the positive correlation between the variables. 
Vol. 2, No. 1, March 2021

Table 9. Coefficients ${ }^{\mathrm{a}}$

\begin{tabular}{|cc|c|c|c|c|c|}
\hline \multirow{2}{*}{ Model } & \multicolumn{2}{|c|}{$\begin{array}{c}\text { Unstandardized } \\
\text { Coefficients }\end{array}$} & $\begin{array}{c}\text { Standardized } \\
\text { Coefficients }\end{array}$ & \multirow{2}{*}{ Sig. } & \\
\cline { 2 - 4 } & B & Std. Error & Beta & & \\
\hline \multirow{4}{*}{1} & (Constant) & -291.581 & 268.080 & & -1.088 & .292 \\
Nifty & .290 & .032 & .837 & 9.185 & .000 \\
& $\begin{array}{c}\text { Points } \\
\text { Crude Oil }\end{array}$ & 10.011 & 4.113 & .222 & 2.434 & .026 \\
\hline
\end{tabular}

a. Dependent Variable: Gold Price

It is also found from the analysis that the there is no relationship between Nifty points and Crude oil price.

\section{Conclusion}

Based on the present analysis, it has been found that there was an association between the gold price fluctuation with respect to crude nifty points and crude oil price. It is also revealed from the study that the price of gold had an exponential increase over a period of two decades and alongside the Nifty points also increased in the same period of time. On the whole, it is found from the data that the gold price is having the positive relation with Nifty points of the stock market and the crude oil price did not have any influence on the determination of gold price.

\section{References}

Andian, Harry. Lanier, Nalley \& Darron Hudson (2009) The Relationship Between Oil, Exchange Rate and Commodity Prices, Journal of Agricultural and Applied Economics. 41, 2. 501-510

Karunakaran, Girish., Choudhary, Nidhi \& Purohit, Harsh (2015) The Relationship Between Gold Prices and Exhange Value of US Dollar in India. Emerging Markets Journal. Vol.5. No-1.

Larry, Sjaastad (2008) The Price of Gold and Exchnage Rates: Once Again. Resources Policy. Vol.33. Issue-2. pp.118-124.

Muhammad, Ashiq AM \& Shanmugasundaram, G (2020) "Impact of oil prices and Exchange Rates on Major Sectoral Indices in India., OPEC Energy Review, 44: 140-161. doi:10.1111/opec.12177.

Naliniprava, Tripathy (2016). A Study on Dynamic Relationship Between Gold Price and Stock Market Price in India. European Journal of Economics, Finance and Administrative Sciences. Issue.88. Aug-2016. 
Vol. 2, No. 1, March 2021

Ranjusha, N., Devasia, M.D \& Nandakumar.V.T (2017) Cointegrating Relation Between Exchange Rate and Gold Price. International Journal of Research-Granthaalayah. Vol.5. Issue.10. 263-269

Samveg, Patel (2013) Causal Relationship Between Stock Market Indices and Gold Price: Evidence from India. The IUP Journal of Applied Finance, Vol. 19, No. 1. January 2013

Sankararaman, G.,Suresh, S., Komatheswari,T., Surulivel,S.T., Selvabaskar,S., Vijayanand,V \& Rengarajan (2018). A Study on Relationship Between Price of US Dollar and Selected Commodities. International Journal of Pure and Applied Mathematics. Volume. 119. No.15. 203-224.

Securities and Exchange Board of India. Annual Reports.Various Years. Web Link: https://www.sebi.gov.in/sebiweb/home/HomeAction.do?doListing=yes\&sid=4\&ssid=80 \&smid=101. Accessed on 16/4/20.

Subashini, S \& Poornima, S (2014) An Empirical Investigation of Causal Relationship Between Gold Price, Exchange Rate and Crude Oil Price. International Journal of Management Research and Review. Vol.4. Issue-10. pp.981-987.

\section{Copyrights}

Copyright for this article is retained by the author(s), with first publication rights granted to the journal.

This is an open-access article distributed under the terms and conditions of the Creative Commons Attribution license (http://creativecommons.org/licenses/by/4.0/) 